\title{
HISTORY
}

\section{Orthodoxy during the Great Patriotic War on the Pages of the Newspaper "Severny Rabochy"}

\author{
D. A. Buyukli ${ }^{1}$
}

${ }^{1}$ P. G. Demidov Yaroslavl State University, 14 Sovetskaya str., Yaroslavl 150003, Russian Federation

DOI: $10.18255 / 1996-5648-2021-1-46-53$

Research article Full text in Russian

The article presents the results of a study of the Russian Orthodox Church in the view of readers of the Soviet press on the example of the Yaroslavl regional newspaper "Severny Rabochy" during the great Patriotic war. The study shows how the image of an Orthodox person was constructed, and what aspects of religious life were in sight of Yaroslavl correspondents. The conclusion is made about the ways to form public perception in a censored printed edition.

Keywords: orthodoxy; newspaper; church; atheization; mass media

INFORMATION ABOUT AUTHORS

\begin{tabular}{l|l} 
Buyukli Darya A. & $\begin{array}{l}\text { E-mail: darya.buyukli@mail.ru } \\
\text { Postgraduate }\end{array}$
\end{tabular} 


\section{Православие в годы Великой \\ Отечественной войны на страницах \\ газеты «Северный рабочий»}

\section{Д. А. Буюкли ${ }^{1}$}

19рославский государственный университет им. П. Г. Демидова, ул. Советская, 14, Ярославль, 150003, Российская Федерация

DOI: $10.18255 / 1996-5648-2021-1-46-53$

УДК 94(47)

Научная статья

Полный текст на русском языке

В статье приводятся результаты исследования того, какой представала Русская православная церковь в глазах читателей советской прессы на примере ярославской областной газеты «Северный рабочий» в годы Великой Отечественной войны. Показано, каким образом конструировался образ православного человека, какие аспекты религиозной жизни попадали в фокус ярославских корреспондентов. Сделаны выводы о способах формирования общественного мнения в подцензурном печатном издании.

Ключевые слова: православие; газета; церковь; атеизация; средства массовой информации

\section{ИНФОРМАЦИЯ ОБ АВТОРАХ}

Буюкли Дарья Андреевна $\mid$ E-mail: darya.buyukli@mail.ru Аспирант

Период Великой Отечественной войны характеризуется масштабными и во многом беспрецедентными изменениями в жизни советских людей, перераспределением социальных функций в обществе и государстве. К числу организаций, активизировавших свою деятельность и взявших на себя дополнительные обязанности в период мобилизации, относилась Русская православная церковь (далее - РПЦ). Несмотря на то что вклад священнослужителей и верующих в достижение долгожданной победы был оценен много позднее, тенденция к «потеплению» в государственно-церковных отношениях прослеживалась уже с начала 
$1940-$ х гг. Картину изменения образа Церкви и верующих в глазах обывателей можно проследить, обращаясь к периодической региональной печати того времени.

Как исторический источник оценивать советскую периодику следует в ракурсе времени. С конца $1920-$ х гг в СССР отсутствовали частные издательства, была введена жесткая цензура, партийно-государственные органы и организации, входящие в систему, контролировали все газеты, журналы, информационные и пресс-бюллетени. Тем не менее советская, в том числе региональная, периодика по праву считается не только важнейшим инструментом пропаганды, но и незаменимым источником по истории того времени, отражавшим все аспекты общественной жизни. На страницах газет печатались статьи информативного, аналитического и художественно-публицистического характера. Читателей знакомили с официальной нормативной документацией и партийными материалами, а также заметками, содержащими оценочные и пропагандистские суждения в отношении практически всех сторон жизни населения.

Какой же образ религиозного, православного человека создавался в сознании советского обывателя, читающего центральные и местные газеты? Какой видели Русскую православную церковь ярославцы?

По сообщению исследователя В. Якунина, И. В. Сталин уже в 1941 г. порекомендовал Е. М. Ярославскому, возглавлявшему Союз воинствующих безбожников, публично отметить новую патриотическую позицию Церкви. Так, последний 2 сентября 1941 г. подготовил статью «Почему религиозные люди против Гитлера» для печати, подписав её псевдонимом Каций Адамиани1. Первоначально статью предполагалось адресовать только зарубежному читателю. «В ней Е. Ярославский высоко оценивал новую патриотическую позицию Церквей и религиозных организаций Советского Союза» [1]. Деятельность Союза воинствующих безбожников угасла к началу 1941 г., хотя формально он просуществовал до 1947 г. Всё чаще в прессе появляются статьи о религиозной политике в других государствах. Язвительный по отношению к религиозным деятелям подтекст, преобладавший в 1930-е гг., уступил место сочувствен-

${ }^{1}$ Каций Адамиани - аллюзия на название произведения известного грузинского поэта, публициста и общественного деятеля, уделявшего особое внимание национальной независимости Грузии, Ильи Григорьевича Чавчавадзе. 30 августа (12 сентября) 1907 г. он, по мнению некоторых исследователей, стал жертвой политического убийства, хотя заказчики так и не были найдены. Чавчавадзе канонизирован Русской православной церковью в 1987 году. Среди известных работ имеется повесть «Кациа-Адамиани» («И это человек?» - пер. с грузинского. Дословный перевод - «И это мужчина?» 
ному тону, стремлению подчеркнуть единение и солидарность верующих всех стран.

Статья об убийстве польских евреев в синагоге появилась в «Северном рабочем» 27 июня 1941 года [2]. 8 июля 1941 г. «Правда» осведомляла население СССР о гонениях на католиков в Германии [3]. Владимирская областная газета «Призыв» 28 сентября 1941 г. поместила статью о гонениях на католическую церковь в Польше [4], а 16 ноября 1941 г. опубликовала выдержки из американского журнала о нацистских планах уничтожения религии [5]. Исследователь советской прессы Ю. Г. Чиндяйкин сообщает, что в 1941-1945 гг. отношение населения к печатной информации менялось в лучшую сторону, что было связано с качественными изменениями в содержании газетных материалов. Если в довоенный период «...преобладала официальная, агитационно-пропагандистская информация...», то в военное время "... большое количество газетных площадей выделяется для заметок, статей о подвигах жителей <..> на фронте и в тылу, появляются публикации о религиозных организациях. Все это больше соответствовало духовным потребностям читателей» [6].

На примере крупнейшей газеты Ярославской области «Северный рабочий» проведем анализ материалов периодической печати. С первых дней войны работа в редакции не прекращалась ни на день; газета выходила 6 дней в неделю (кроме понедельника). На посту главного редактора до апреля 1943 г. находился Виктор Георгиевич Кашин, затем его сменил Иван Васильевич Лопатин. По воспоминаниям его коллеги, заведующей отделом Сарры Мироновны Войскобойниковой, «был он строг, требователен, но вместе с тем прост и душевен в общении. С ним как-то энергичнее завертелось колесо редакции. Заметно это стало и читателям. Потеплел общий тон публикаций» [7, с. 90].

Максимальный тираж газеты - 60000 экземпляров - приходился на 1941 г. Нехватка бумаги не позволяла сделать газету более полной, поэтому она выходила три раза в неделю всего на двух страницах, а в остальные дни - на четырех. Основная информация, сообщавшаяся в данном печатном издании, касалась оперативной сводки с фронта, жизни ярославских заводов, фабрик и колхозов, событий в стране и мире.

Деятельность РПЦ и православных в годы войны в «Северном рабочем» освещалась скудно, но позволяла читателям составить впечатление о священнослужителях в военное время, морально-ценностных ориентирах верующих, изменившейся парадигме церковно-государственных отношений. Материалы о религиозной жизни людей можно классифи- 
цировать по содержанию и выявить следующие категории: 1) материалы о религиозной политике в других странах, 2) о деятельности священнослужителей РПЦ, 3) об исторических православных деятелях, 4) о православной архитектуре, 5) иллюстрации, содержащие православные символы/элементы архитектуры. В отличие от всесоюзных газет, например «Правды», на страницах «Северного рабочего» не было уделено должного внимания сведениям о награждениях священнослужителей и некрологах.

На основе анализа подшивки газеты за годы войны была составлена таблица 1.

Таблица 1

\section{Религиозная политика на страницах газеты «Северный рабочий»}

в годы Великой отечественной войны

\begin{tabular}{|c|c|c|c|c|c|c|c|c|c|c|}
\hline \multirow{3}{*}{$\begin{array}{c}\text { Содержание } \\
\text { публикации }\end{array}$} & \multicolumn{10}{|c|}{ Количество публикаций } \\
\hline & \multicolumn{2}{|c|}{1941 г. } & \multicolumn{2}{|c|}{1942 г. } & \multicolumn{2}{|c|}{1943 г. } & \multicolumn{2}{|c|}{1944 г. } & \multicolumn{2}{|c|}{1945 г. } \\
\hline & абс. & $\%$ & абс. & $\%$ & абс. & $\%$ & абс. & $\%$ & абс. & $\%$ \\
\hline $\begin{array}{l}\text { Материалы о рели- } \\
\text { гиозной политике } \\
\text { в других странах }\end{array}$ & 3 & 33,3 & 2 & 11,8 & 3 & 33,4 & & & 1 & 33,3 \\
\hline $\begin{array}{l}\text { Материалы о дея- } \\
\text { тельности священ- } \\
\text { нослу-жителей РПЦ }\end{array}$ & 1 & 11,1 & 2 & 11,8 & 2 & 22,2 & & & & \\
\hline $\begin{array}{l}\text { Материалы об исто- } \\
\text { рических право- } \\
\text { славных деятелях }\end{array}$ & 5 & 55,6 & 6 & 35,3 & 2 & 22,2 & 2 & 25 & 2 & 66,7 \\
\hline $\begin{array}{l}\text { Материалы } \\
\text { о православной } \\
\text { архитектуре }\end{array}$ & & & 5 & 29,3 & 1 & 11,1 & 5 & 62,5 & & \\
\hline $\begin{array}{l}\text { Иллюстрации, } \\
\text { содержащие пра- } \\
\text { вославные сим- } \\
\text { волы/элементы } \\
\text { архитектуры }\end{array}$ & & & 2 & 11,8 & 1 & 11,1 & 1 & 12,5 & & \\
\hline Всего & 9 & 100 & 17 & 100 & 9 & 100 & 8 & 100 & 3 & 100 \\
\hline
\end{tabular}

Чаще всего в печать попадали сообщения о религиозной политике за рубежом. Большая часть материалов была посвящена расправам фрашистов над священнослужителями и прихожанами, а также ущемлению прав верующих и клира, обстановке в Польше, что объясняется диплома- 
тической ситуацией, возникшей между двумя странами, и «непрочностью советско-польского военного союза» [8, с. 23].

Материалы о деятельности священнослужителей и РПЦ как организации представлены всего несколькими статьями, но сам фракт подобных публикаций, несомненно, свидетельствовал об изменениях в государственно-церковной политике. Наибольшего внимания заслуживает статья о Поместном соборе. В ней не только были перечислены основные деятели церкви военного периода, но и освещались вопросы «о деятельности Русской Православной Церкви в дни Великой Отечественной войны <..> о духовных учреждениях» [9], об избрании и интронизации Патриарха. Автор статьи подчеркивает положительное отношение советских властей к Поместному Собору, упоминая присутствие председателя Совета по делам Русской православной церкви Г.Г. Карпова и принятие Поместным Собором обращения к Правительству СССР. Открытость сторон к диалогу подчеркивается словами: «Поместный Собор приветствовал председатель Совета...» и «Собор единодушно принял обращение к Правительству».

Появление материалов о выдающихся исторических деятелях России свидетельствует о стремлении закрепить связь между великими защитниками Отечества и современными читателям солдатами. Исторически сложилось так, что патриотическая деятельность таких знаменитых людей, как Кузьма Минин, Дмитрий Пожарский, Александр Невский, Дмитрий Донской, Александр Суворов, Михаил Кутузов, неразрывно связана с их религиозной позицией. Об этих выдающихся личностях пишут статьи, снимают фрильмы, читают лекции. Кинотеатры «Летний», «Горн» и клуб «Гигант» проводили до четырёх сеансов в день, чтобы продемонстрировать всем желающим ленты «Александр Невский», «Минин и Пожарский», «Суворов». На страницах газеты широко освещался кинофрестиваль «Наши великие предки», в программу которого вошли фрильмы об Александре Невском и Минине и Пожарском [10]. Заслуживает внимания и постановка Костромского театра «Козьма Минин» [11].

Не все статьи содержали положительные отзывы о деятельности православных клириков. Как бы в назидание современным священникам, поверившим лозунгам, которые распространяли фашисты, в статье о сражении на Туговой горе упоминается эпизод с предательством монаха Изосима [12].

Материалов, касающихся православной архитектуры, храмов, церквей, на страницах газеты за время Великой Отечественной войны поя- 
вилось не так много. Но для читателя ценен сам фракт снятия негласного моратория на упоминание названий соборов и монастырей, пусть даже с оговоркой «бывший». Многие статьи пронизаны трагическим настроением автора, понимающего масштаб потери того или иного памятника истории и архитектуры, а также места духовного единения верующих. Из материалов расследования Государственной Чрезвычайной Комиссии следует: «Покровскую церковь немцы разграбили и увезли все ценности. В церкви они устроили казармы для солдат. Священника Андрея Попова расстреляли. Перед отступлением фашисты заминировали церковь и согнали туда около 200 мирных жителей. Тех, кто отказывался идти или не мог дойти до церкви - мужчин, женщин и детей, фашисты расстреливали “за неповиновение немецким властям” [13].

Иллюстраций как таковых в «Северном рабочем» было немного, что, как уже отмечалось ранее, связано с экономией бумаги, краски и низким уровнем технического развития фротодела. Но и на нечетких снимках порой можно заметить купола церквей. Примечательно, что широко освещаемое в прессе строительство Которосльной набережной в 1944 г. в качестве эмблемы имело изображение будущей набережной - и на ней четко обозначен храм [14].

Подводя итог, хотелось бы отметить, что Великая Отечественная война изменила жизнь советских людей. В экстренном режиме работали многие службы и организации. Любая помощь могла иметь решающее значение, и РПЦ не могла остаться безучастной. Советская периодика, особенно регионального уровня, не спешила подстраиваться под изменившуюся парадигму государственно-церковных отношений. Количество материалов, раскрывающих деятельность РПЦ, от года к году не увеличивалось. Но, как говорят, редакция «держала руку на пульсе времени». К началу 1940-х гг. из печати ушла антицерковная пропаганда, появилось больше материалов о деятельности священнослужителей на фрронте и в тылу, о современном состоянии православия в стране, о признании значимости религиозных памятников, зданий, ценностей. Формированию положительного отношения к активности Русской православной церкви способствовало практически полное отсутствие негативных статей о православных деятелях. 


\section{Ссылки}

1. Правовой статус, положение, деятельность, внешние связи Русской Православной Церкви в годы Великой Отечественной войны, 1941-1945 гг.: автореф. дис. ... д-ра ист. наук. Самара, 2002. 445 с.

2. Северный рабочий. 1941. 27 июня, № 149.

3. Правда. 1943.8 сент., № 249.

4. Призыв. 1941. 28 сент., № 226.

5. Призыв. 1941. 16 ноябр., № 262.

6. Чиндяйкин Ю. Г. Печать Мордовии в 1928-1953 гг.: автореф. дис. ... канд. ист. наук. Саранск, 2002. 187 с.

7. Ярославская журналистика: страницы истории: очерки / сост. И. В. Пухтий. Ярославль, 2018. 339 с.

8. Заец С. В.Советско-польский военный союз(1941-1942)//Вестник Северного (Арктического) фредерального университета. Серия: Гуманитарные и социальные науки. 2009. № 6. С. 22-27.

9. Северный рабочий. 1945. 7 февр., № 25.

10. Северный рабочий. 1942. 20 сент., № 223.

11. Северный рабочий. 1944. 29 янв., № 20.

12. Северный рабочий. 1942. 20 февр., № 43.

13. Северный рабочий. 1944. 7 мая, № 91.

14. Северный рабочий. 1944. 10 сент., № 180. 